\title{
A Educação Socrática como "Modo de Vida": a Imagem do "Cuidado de Si” na Beleza Poética do Sátiro
}

\author{
Carlos Roberto da Silveira*
}

\begin{abstract}
Resumo
A obra $O$ Banquete de Platão é complexa, inesgotável, instigante e de suma importância para os estudos filosófico, educacional, existencial, espiritual. Aqui se alude a um pequeno trecho desta obra (174a), pois acredita-se que contenha os movimentos da educação socrática através do "Conhece-te a ti mesmo", do "Cuidado de si e dos outros", dos "Exercícios espirituais", que constituem o "Modo de vida". Deste parágrafo algumas perguntas emergiram instantaneamente e análises foram realizadas, mas ao longo do estudo, outras tantas surgiram. Enfim, espera-se que estas interrogações aqui contidas, suscitem, fermentem também outras questões nos educadores e que estes promovam discussões, análises, reflexões e ações sobre a beleza da sua missão, de sua poiésis no auxílio ao trabalho do parto, da Escultura de Si e dos Outros.
\end{abstract}

Palavras-chave: Sócrates; Platão; Alcibíades, Cuidado de si, Educação.

\section{The Socratic Education as "Way of Life": the Image of the "Self-Care" in Poetic Beauty of Satyr}

\begin{abstract}
Keywords: Socrates; Plato; Alcibiades; Self-care; Education.

Apolodoro dirá: “(...) é preferível expor tudo do começo, na mesma ordem em que Aristodemo me contou. Disse-me que encontrara Sócrates saído do banho e ainda de sandálias, o que mui raramente acontecia. Perguntou-lhe, então, aonde ia assim tão belo. Ao banquete de Agatão [Agathón], respondeu; ontem, de medo da multidão, esquivei-me dele, quando celebrava o sacrifício da vitória. Mas prometi comparecer hoje. Esse o motivo de me ter aprontado. Para visitar um belo rapaz, preciso me fazer belo" (PLATÃO, 2011, 174a).
\end{abstract}

The work The Banquet of Plato is complex, inexhaustible, instigating and very important for studies in philosophy, education, existential and spiritual. A small passage of this work (174a) is alluded to here, because it is believed that it contains the movements of Socratic education through the "Know yourself", the "Care of the self and of the other", the "Spiritual exercises", which constitute the "Way of life". Some questions have crop up from this paragraph and analyzes were done, but over the course of the study, many others have emerged. Finally, it is expected that the questions contained herein, spark, or ferment other important issues among teachers, so that, they may promote analyzes, discussions and actions, on the beauty of their missions, from their poiésis to support their jobs of birth, the Sculpture of Self and Others.

\section{Considerações Iniciais}

O diálogo platônico inicia-se com a conversa entre Apolodoro e um companheiro desconhecido. Apolodoro é quem narra sobre o que ocorrera no banquete dedicado a Eros, isso devido a ajuda de Aristodemo que antes, já havia lhe contado sobre o referido festim. Neste sympósium ${ }^{1}$, Agatão comemora a sua vitória diante do concurso trágico ocorrido no dia anterior. Ele convida os amigos para compartilhar o seu sucesso e ao mesmo tempo, para tratar do importante assunto relativo a Eros. Fedro assumiu o papel de simposiarca, o responsável pela condução dos discursos e também o primeiro a discursar por ser o idealizador do tema sobre o Eros. Em seguida, discursaram os grandes personagens da pólis grega, o orador Pausânias, o médico Erixímaco, o comediógrafo Aristófanes, o tragediógrafo Agatão, o filósofo Sócrates e por último, com uma entrada triunfal, o famoso general Alcibíades.

A obra $O$ Banquete, do filósofo Platão (428/427 - 348/347a.C.) é complexa, intensa, inesgotável, instigante, de suma importância para o estudo filosófico, educacional, existencial, espiritual. Escrita aproximadamente a 384 a.C., torna-se viva a cada nova leitura, os leitores tornamse viajantes no tempo, convivas sempre recémchegados à casa de Agatão. $\mathrm{O}$ "encontro" com este passado é um presente em todos os sentidos e realmente convida a todos para "examinar a vida" como declarava o tavão Sócrates, pois os diálogos da obra, no "encontro" com os leitores serão sempre

\footnotetext{
* Endereço Eletrônico: carlosilveir@yahoo.com.br
} 
provocativos.

Tal provocação é notada ao longo da história da civilização ocidental, como se vê, por exemplo, nas escritas de Vitor Sales Pinheiro (2011, p.27-29) impressas na Introdução à referida obra de Platão, $O$ Banquete. Ele escreve que a obra tornouse um modelo de banquetes literários e inaugurou um gênero peculiar denominado "ceia", relação entre o drama e a oratória. Então, cita algumas obras, como o Convívio de Dante (1307), o Decameron de Boccaccio (1353), a Cena de le Ceneri (ou Jantar da Quarta-feira de Cinzas - 1584) de Giordano Bruno, Les Soirées de SaintPétersbourg de J. de Maistre (1821), In Vino Veritas, incluído em as Etapas no Caminho da Vida de Kierkegaard e o The Cocktail Party de T.S. Eliot (1949). Traduzido para o francês por Racine (1686) e para o inglês em 1818 por Shelley, $O$ Banquete entra na era da imagética romântica e contribuiu para o erotismo da psicanálise de Freud, Além do Princípio do prazer (1920) e A Resistência da Psicanálise (1925). Motivou o Seminário sobre a Transferência (1960-1961) de Lacan que se apropriou da obra de Ficino (Comentários sobre o Banquete de Platão, Sobre o amor - 1469), que trata da cristianização neoplatônica da obra $O$ Banquete, realizada pelos padres da Igreja do século III, como Orígenes, Metódio e Agostinho que transformam o amor platônico, no centro da mística teológica medieval que se estende ao século VI, com Dionísio, Pseudo-Aeropagita. Na Antiguidade, Xenofonte também escreveu sobre $O$ Banquete $(360$ a.C.) tendo Sócrates por seu mestre. Do diálogo platônico, Aristóteles na Ética à Nicômaco, atém-se à vida contemplativa, bem como, à dos atributos ontológicos da forma do Belo, ao descrever a essência de deus na Metafísica (350 a.C.). No século III d. C., Plotino escreve um Tratado sobre o Amor (Enéadas,III,5) retomando a dimensão espiritual de Platão. Na cultura do Império Romano (esfera das obras literárias pagãs), o amor socrático é tratado no Satiricon de Petrônio (sec. I d.C.), no Érotikos de Plutarco (aprox. 110 d.C.) e no Metamorfoses de Apuleio (sec. II d.C.). No Renascimento, $O$ Banquete influenciaria a obra Diálogos de Amor de Leão Hebreu (1535), que adentraria o humanismo de Camões e Cervantes e o Cortesão de B. Castiglione. No século XX, T. Mann escreve Morte em Veneza (1912), P. Valéry, A Alma e a Dança e Eupalinos ou o Arquiteto (1921), Virgínia Woolf, To the Lighthouse (1927), E. M. Foster, Maurice (1971), R. Barthes, Fragmentos de um Discurso Amoroso (1977), I. Murdoch, Art and
Eros (1986). No universo filosófico, seguem algumas obras, como: On Plato's Symposium (1959) de L. Strauss; Eros und Sein (1965) de H. Buchner; Plato's Symposium (1968) de S. Rosen; Love and Friendship (1993) de A. Bloom. Além disso, existem infinidades de obras e trabalhos acadêmicos especializados e dentre nós, citam-se alguns: Eros: dialética e Retórica (2001), de Donaldo Schüller; Do Elogio à Verdade (2001) de Dion Macedo; Amor, Discurso, Verdade (2005) de Carla Francalanci; O Sopro do Amor (2006) de Irlei Franco; Platônica (2011) de Henrique C. Lima Vaz.

Ainda sobre o "provocativo" que a obra produz, este trabalho, pretende examinar em específico, o texto em alusão (acima), que se inicia com a narrativa de Apolodoro. $\mathrm{O}$ trecho pode passar despercebido durante a leitura completa da obra. Pode parecer sem muita valia, algo comum, uma breve e simples passagem diante dos importantes discursos dos convivas. Mas, ao se deter mais um pouco no referido parágrafo, no diálogo provocativo entre o leitor e a obra, algumas perguntas iniciais pulsam e afloram instantaneamente: neste trecho, a ironia socrática se faz presente? Tal parágrafo conterá alguma mensagem essencial sobre a filosofia socrática/platônica? Quereria Platão revelar algo importante através da fala, do também discípulo de Sócrates, Aristodemo de Cidateneu? Conteria essa passagem, as trilhas, os caminhos ou as estradas que os educadores juntos, podem palmilhar e partilhar com a educação atual? Enfim, passado o reflexo instantâneo, outras perguntas aos poucos põem-se a fermentar e se avolumam, mas para o momento, estas interrogações iniciais bastam.

\section{Sócrates um educador}

Sabe-se que Sócrates (469-399a.C.) dava pouco valor aos bens materiais, às convenções e às honrarias. Era um homem livre das invejas, da vaidade, dos arranjos e conchavos, da soberba e das mesquinharias. Diante disso, talvez pudesse ser uma forma de justificar sua ignorância, pois de "nada sabia" e assim, era um ignaro, "um estranho à vida cotidiana" dentro de uma Atenas repleta de homens "ditos sábios". Condenado por tais "sábios", em sua apologia diante do tribunal popular dos heliastas (399a.C.), ele declara que não fazia outra coisa senão persuadir a todos a não cuidar afoitamente do corpo, das posses e riquezas, mas "melhorar o mais possível a alma, dizendo-vos que dos haveres não vêm a virtude para os homens, mas da virtude vêm os haveres e todos os outros bens particulares e 
públicos" (PLATÃO, 1999, p.57). Era o seu ofício divino, ajudar a parir novas ideias através do método da Ironia e Maiêutica. A palavra ironia (eironéia) não se trata de constrangimento, de deboche, mas de instrumento de aporia, de exame e entendimento, pois deriva da palavra grega eirein, ou seja "dizer" sobre as coisas, purificando o pensamento. Após esta fase, entra-se no processo de gestação e parto com a maiêutica (maieutiké), pois é preciso dar luz às novas ideias. Tal método, inicialmente, promove a descrença dos fundamentos discursivos dos interlocutores, tornando-os frágeis (Ironia). Em seguida (Maiêutica), Sócrates faz com que seus interlocutores sintam-se grávidos de ideias e depois, passem a sentir as dores do trabalho de parto. Na obra Teeteto de Platão, traduzido por Giovanni Reale, Sócrates diz: $\grave{E}$ che tu hai le doglie, caro Teeteto, perché non sei vuoto, ma gravido $(2014,148 \mathrm{e})$ - "É que tu tens dores, caro Teeteto, porque tu não estás vazio, mas grávido (trad. nossa).

Tal como a sua mãe Fenareta que era parteira e o seu pai Sofronisco que era escultor, parece que Sócrates reuniu as duas artes criativas (poiésis) em uma única e criou a do "Educador", pois ajudava as pessoas grávidas pelo saber a darem a luz, bem como, as esculpia, ajudando-as a se tornarem belas, numa Escultura de si.

\section{A imagem do Sátiro}

De volta a $O$ Banquete, lê-se que Sócrates para ir à casa de Agatão ou Aghatón (Aghatós em grego significa "bom”, portanto Agatão é “o Bom”), ele se aprontou, embelezou-se e calçou as sandálias.

Nesta obra, mais adiante no "discurso" ou melhor, no "elogio" de Alcibíades a Sócrates, este compara o mestre à figura dos silenos e à do sátiro flautista Mársias. Os silenos ou também sátiros, eram divindades campestres adoradores do deus Dionísio. Tais seres, possuíam calda e cascos como os de bode ou os de boi, com pequenos chifres e rosto humano, portanto eram "estranhos", terrivelmente "feios". Quanto ao sileno Mársias, na Mitologia Greco-romana conta-se que a deusa Atena (Minerva) havia inventado a flauta e ela entoava belas melodias de seu instrumento. Porém, certa vez, Eros (Cupido) riu das caretas que a deusa fazia ao soprar a flauta. Furiosa, a deusa jogou o instrumento para longe de si, vindo este a cair na Terra, próximo a Mársias. Este pegou o instrumento e logo estava produzindo raras músicas a ponto de ironizar e desafiar o deus Apolo (Febo) com a sua lira. Apolo aceitou o embate e o venceu. Devido a prepotência de Mársias (ou também de Apolo), este não escapou do castigo e foi esfolado vivo. Apolo arrependido, transforma Mársias em um Rio e depois quebra a sua lira. Cabe aqui, neste momento, uma alusão à flauta. Alcibíades à altura de começar seus estudos com os seus mestres de música, recusou-se a tocar flauta, por entender que tal atividade era indigna e vil para homens livres. Assim como Eros, ele declarou que o movimento do sopro modificava as feições (deixava-o feio), a ponto de até os seus familiares não o reconhecerem, além disso, o instrumento tapava a boca e impedia a voz, a "palavra", ou seja, quem sabe, se referia ao lógos, por isso deveria este instrumento ser tocado apenas pelos escravos. Já com a Lira, instrumento divino do deus Apolo, são os dedos que interagem com o instrumento, portanto pode-se falar, cantar normalmente e proferir a palavra (o lógos). Plutarco (2010, p.32,33) declara que este discurso do menino Alcibíades foi levado muito a sério:

Com estes argumentos, meio a brincar meio a sério, Alcibíades abandonou este instrumento e levou a que outros jovens o fizessem. É que depressa se espalhou entre os da sua idade a ideia de que Alcibíades tinha razão quando repudiava a flauta $e$ troçava dos que aprendiam a tocá-la.

Sendo assim, em comparação aos silenos e a Mársias, inicialmente parece que o banho e os adereços de Sócrates pouco serviriam para amenizar a sua estranheza e feiura, mesmo declarando que, para visitar um belo rapaz Aghatón, o Bom, ele deveria se fazer Kalon, Belo.

Convém atentar que entre a feiura e a beleza, Alcibíades (450-404 a.C.) era o símbolo de beleza, de certo modo a imagem mais apropriada e aclamada na Grécia Antiga. Alcibíades era descendente de família nobre. $\mathrm{Na}$ batalha de Artemísio (480 a.C.), Clínias, seu pai, fora glorioso, mas décadas mais tarde em Coroneia (447 a.C), este faleceu em batalha. Então, ainda muito criança, Alcibíades foi entregue aos cuidados de seu parente, o grande estratego Péricles. Alcibíades fora muito belo fisicamente, isso a cada fase de sua existência, inclusive até a sua morte. Dono de aspectos encantadores e agradáveis, era possuidor de dotes naturais, corpo perfeito, sedutor e consciente de sua exuberante beleza física, além disso, era rico, poderoso, corajoso, um príncipe cercado de aduladores, um exemplo a ser seguido mesmo 
quando adolescente - um herói de guerra, em quem até o defeito de pronúncia (o de confundir $\mathrm{R}$ com L), conferia-lhe encanto e poder de persuasão em seus discursos. Por um outro lado, numa fase posterior tornou-se instável, inconsequente, tomado por violentas paixões, vaidoso, entregue às bebidas, irresponsável, ambicioso diante da própria função exercida tornou-se arrogante, ríspido, intratável e insolente $^{2}$. Mas na presença de Sócrates transformava-se num Belo rapaz, totalmente diferente, mesmo quando embriagado (veja nO Banquete), pois o filósofo tocava-lhe o coração e a alma. Dirá Werner Jaeger (2001, p.748): “É indubitável que Alcibíades queria ser discípulo de Sócrates, mas a sua natureza não o deixa separar-se de si próprio. O eros socrático ardeu em sua alma por momentos, mas não chegou a atear nela a chama permanente."

\section{O fazer-se Belo e a beleza do Sátiro}

No banquete na casa de Agatão, na sequência do "elogio", Alcibíades faz uma retratação mitigada e expressiva sobre a feiura do mestre Sócrates, o Sátiro. Declara que nas oficinas dos escultores estatuários, imagens dos horríveis sátiros eram produzidas, as quais, em seu interior, continham estatuetas dos deuses, ou seja, apesar de exteriormente feios, tais imagens abrigavam em seu cerne, em seu interior a beleza divina $(2011,215 b)$. Cabe aqui, uma aproximação entre esta fala de Alcibíades e o pedido de beleza interior de Sócrates aos deuses, em que Platão ao final da obra (Fedro), exibe a conhecida oração socrática:

Querido Pã, e todas vós, divindades locais: dai-me alcançar a beleza interna, e que tudo o que eu tenho no exterior fique em consonância o com o que trago dentro de mim; rico me pareça exclusivamente o sábio, e seja todo o meu ouro o que apenas o homem temperante necessite e possa carregar $(2007,279$ c).

Agora com outros olhos, pode-se ver a beleza (Kalon) do Sátiro. Ciente deste olhar sobre o Belo, o "elogio" de Alcibíades se estende e ele declara que Sócrates não precisa da flauta para encantar os homens, pois quando alguém o ouve, ou quando terceiros reproduzem os seus discursos, mesmo não sendo "bons oradores", logo homens, jovens e mulheres se sentem arrebatados. Alcibíades afirma que, quando o ouve, seu coração acelera e os discursos lhe arrancam lágrimas vivas - "Isso é o que se dá comigo e com muitas outras pessoas, sob a influência deste sátiro flautista" (2011, 215e 216c). Agora, cabe apropriar de certas palavras de Sócrates dirigidas a Alcibíades, porém mudando-as de sentido, isso para se produzir uma defesa a Alcibíades para este momento em específico: "Os olhos do espírito só começam a ver com acuidade, quando os do corpo entram a enfraquecer (...)" (2011, 219a). Dessa forma, Alcebíades "viu", quando ouviu a melodia do sátiro e afirmou que tais sons abarcam a todos, pois o discurso de Sócrates atinge o íntimo e ecoa até mesmo, na voz de outras pessoas, mesmo não sendo estas, "bons oradores". Diante disso, Sócrates, o amante da sabedoria fez-se "Belo" e de banho tomado. Aqui, o "Belo" (Kalos) não corresponde à visão estética do homem contemporâneo, mas pertence ao universo da arte de viver, do "Modo de vida", cuja beleza firma-se na virtude verdadeira (Areté) que o torna Bom (Agathós), portanto Belo e Bom (Kalos kai Agathós).

\section{Aristodemo o orador}

Sobre o "qualquer orador", aqui, vale avançar um pouco. “(...) é preferível expor tudo do começo, na mesma ordem em que Aristodemo me contou..." (2011, 174a). A fala de Apolodoro deveu-se às recordações, à "memória" 3 de Aristodemo de Cidateneu que havia participado da grandiosa reunião. $\mathrm{O}$ banquete na casa de Agatão (Ághaton) foi recordado e contado por Aristodemo, homem pequeno, o mais fervoroso admirador e discípulo de Sócrates, segundo Apolodoro (2011, 173b).

Convém lembrar que, assim como o seu mestre, Aristodemo andava sempre descalço e foi ele, quem Sócrates convidou para ir ao referido banquete. Portanto, naquele momento, o do encontro com Sócrates, Aristodemo contrário ao mestre, não havia banhado, era miúdo, estava descalço e além disso tudo, o pior seria, ir ao banquete sem ser convidado. Bom entender, que os dois não sabiam que Agatão havia procurado Aristodemo para lhe fazer o convite, mas não o encontrara. De qualquer forma, Sócrates resolve este pormenor e torna Aristodemo em um convidado seu. Aristodemo reluta em participar do festim, mas Sócrates o convence (2011, 174b-e). Aristodemo lhe diz: “(...) visto que me levas, vai pensando nalguma desculpa, pois não irei confessar que apareci lá como intruso; serei teu convidado" 
(2011, 174c). E Sócrates responde: "Se somos dois, em caminho acertaremos o que será preciso dizer. Partamos, pois" (2011, 174d).

Como se sabe, Sócrates não legou à humanidade uma única palavra escrita, pois ao longo de seu caminho, o diálogo, a oralidade o cálamo (kálamos) foi o seu instrumento filosófico. No embate sobre a Oralidade e a Escrita, na obra "Fedro", ali encontra-se um dado importante sobre o "qualquer orador" e o mesmo não sendo "bom orador":

É que a escrita, Fedro, é muito perigosa e, nesse ponto, parecidíssima com a pintura, pois esta, em verdade, apresenta seus produtos como vivos; mas, se alguém the formula perguntas, cala-se cheia de dignidade. O mesmo passa com os escritos. És inclinado a pensar que conversas com seres inteligentes; mas se, com o teu desejo de aprender, os interpelares acerca do que eles mesmos dizem, só respondem de um único modo e sempre a mesma coisa. Uma vez definitivamente fixados na escrita, rolam daqui dali os discursos, sem o menor discrime, tanto por entre os conhecedores da matéria como os que nada têm que ver com o assunto de que tratam, sem saberem a quem devam dirigir-se e a quem não. E no caso de serem agredidos ou menoscabados injustamente, nunca prescindirão da ajuda paterna, pois por si mesmos são tão incapazes de se defenderem como de socorrer alguém (2007, 275d-e).

Ao se posicionar quanto à Escrita, Sócrates fala da outra forma de modalidade do discurso. Aponta a Oralidade como sendo a irmã legítima desta primeira e declara sua força como capaz de se inscrever na alma, pois grava, esculpe e talha com profundidade, porque advém do conhecimento da alma que foi capaz de se defender, de silenciar ou falar quando preciso. Nisso, Fedro responde que o discurso escrito não passa de simples simulacro e afirmativamente refere-se à Oralidade como o discurso vivo e animado. E Sócrates responde:

Esse mesmo. E agora, dize-me uma coisa: um lavrador inteligente que se interessasse por suas sementes e se empenhasse em vêlas frutificar, iria semeá-las, em pleno verão, nalgum jardim de Adônis, para alegrar-se ante o belo espetáculo da germinação em oito dias? Se o fizesse, seria à guisa de divertimento e não oportunidade de algum festival, não é verdade? Porém, as sementes que lhe fossem verdadeiramente caras, confiaria ao terreno apropriado, de acordo com as regras da agricultura, considerando-se felicíssimo se oito meses depois todas elas houvessem germinado com perfeição $(2007,276 b)$.

Na sequência, Sócrates continua a interrogar Fedro e pergunta se um lavrador que dispusesse de conhecimento do justo, do belo e do bom, não seria menos ajuizado do que o agricultor com as suas sementes? Pelo que parece, Sócrates escolhia seus jardins, não é por menos que Aristodemo conservou na memória os diálogos, conforme declara Apolodoro: "Não obstante, consultei o próprio Sócrates a respeito de vários pontos de sua narrativa, tendo ele confirmado tudo o que o outro me contara" (2011, 173b).

\section{Os prazeres, o vestuário e o banho}

Paul Veyne (2006, p.179) faz uso de um provérbio da Antiguidade: "O banho, o vinho e Vênus [Afrodite] consomem o corpo, mas são a verdadeira vida". Ele declara que o prazer era tão legítimo como a virtude. Isso é confirmado na representação de Héracles em seus momentos de fraqueza aos pés da amada Ônfale ou a imagem dele totalmente embriagado, com o olhar perdido e distante, contudo com o rosto alegre.

Sob a influência da cultura helênica, a cultura romana nas comodidades materiais (commoda) sofisticou "os prazeres" com os banhos públicos durante o período do Império Romano (27a.C.- 476 d.C.). Construíram-se imensos e luxuosos balneários dedicados aos imperadores e abertos ao povo, com banhos quentes, frios e a vapor. Banhar-se era um dos maiores prazeres desse povo. Nesse sentido, um dado interessante é tratado por Veyne (2006, p.193) ao se referir a essa época:

O banho não era uma prática de higiene, $e$ sim um prazer complexo, como a praia entre nós. Os pensadores e os cristãos recusavam tal prazer; não tinham a fraqueza de ser limpos e só se banhavam uma ou duas vezes por mês; a barba suja de um filósofo constituía prova de austeridade, da qual ele se orgulhava. 
Mário Curtis Giordani (1984, p.250-251), declara que os gregos davam muito valor aos exercícios físicos, à higiene corporal e tinham cuidados especiais com os banhos. No séc.VI a.C. em Atenas, havia fontes cuja construções continham duchas, porém no séc. V a.C. estas duchas foram substituídas aos poucos por abluções em fontes, pias e piscinas dos ginásios e palestras. Neste ínterim surgiram os banhos públicos instalados pelo Estado e estes locais se tornaram pontos de distração e prazeres. Barbeiros e cabelereiros ofereciam serviços para melhorar os aspectos físicos, além disso, como bons conversadores, ficavam à caça de novidades dos fregueses. Estes profissionais cuidavam do cabelo, da barba, das unhas dos pés e das mãos. Cabelos longos só para homens elegantes, como Alcibíades ou alguns filósofos excêntricos. Atenienses usavam penteados complicados, tingiam e perfumavam os cabelos. Barba e bigode raspados, só foram adotados depois de Alexandre o Grande.

No sympósium (banquete), os convivas recebidos eram descalçados e tinham os seus pés lavados pelos escravos. Noutra sala era lhes oferecido água para lavarem as mãos. Quanto ao vestuário helênico, Giordani descreve sobre algumas peças, mas declara que não é fácil apresentar tal assunto, devido a sua diversidade, pois “(...) na Antiguidade Clássica a moda evoluiu e sofreu as consequências dos acontecimentos políticos e sociais" (1984, p. 251).

Neste período Clássico, Agatão fazia parte da moda helênica, do cuidado, da vaidade extrema com o corpo e vestimentas. Era jovem, belo, delicado, fino, inteligente, foi considerado um gorgiazein (falava como Górgias, filósofo retórico e sofista) e pupilo de Górgias. Devido a sua beleza afeminada, conforme aponta Aristófanes em sua obra Tesmoforiantes, Agatão foi confundido por um parente de Eurípedes, Mnesíloco que o considerou uma mulher, pois estava de faces raspadas, rede no cabelo e com trajes femininos como os de uma prostituta, exatamente para compor e representar um de seus dramas trágicos (bom lembrar, que a barba era símbolo de masculinidade e virilidade). A confusão e excitação aumentou mais ainda, quando Agatão ao cantar, encantou, pois possuía voz de timbre suave e feminino. Logo, ele esclarece que os trajes deveriam coincidir com a forma da representação. "Supongamos que uno compone un drama de mujeres. Pues bien, su cuerpo tiene que tener parte de los hábitos de aquéllas" (ARISTÓFANES, 2007, p.132). Conforme Agatão, para representar as mulheres, o poeta precisa participar da natureza feminina, fazer uso de seu corpo e vestuário, para ser convincente em sua imitação. Na Obra $O$ Banquete, Agatão foi aclamado pela multidão durante o concurso, certamente porque assumiu o seu papel vivificante da representação, que, aliado aos elementos coadjuvantes como o cenário, as roupas e o coro auferiram-lhe o sucesso.

Era uma das virtudes para o homem grego, buscar a perfeição em tudo que fizesse, como exemplo, a excelência em seu ofício. Agatão pelo seu dom e natureza, comprovou sua Beleza. Alcibíades reafirma isso, no banquete, em uma cena que envolve Agatão. Alcibíades embriagado adentra a casa do anfitrião e se joga ao lado deste e de Sócrates, mas não enxerga Sócrates. Porém, quando o vê, dá um salto e exclama: "Que fazes aqui, e por que escolheste precisamente este lugar? Por que não junto de Aristófanes ou de outro farsante de verdade ou que deseje sê-lo? Ao invés disso, arranjaste meio de ficar junto do rapaz mais belo de toda a companhia" (2011, 213c).

A beleza era sempre querida. Como se sabe, Alcibíades tinha uma relação de ódio e amor por Sócrates, que está declarada em seu "Elogio a Sócrates" nO Banquete. Desse trecho, cabe aqui uma passagem importante narrada por Alcibíades, dita por Sócrates:

Meu caro Alcibíades, não pareces muito tolo, se for verdade o que disseste a meu respeito | e eu possuir, realmente, o poder de aperfeiçoar-te. Com isso, terias descoberto em mim uma beleza incomparável, que supera infinitamente a beleza de tuas formas. Se depois de tal descoberta, pensas em entrar em entendimento comigo para trocarmos beleza por beleza, é por quereres obter à minha custa uma grande vantagem: nada mais nada menos do que trocar tua aparência pela verdadeira beleza, o que é, positivamente, trocar | bronze por ouro. Porém, meu bem-aventurado amigo, examina o assunto mais de siso; talvez estejas enganado e nada disso haja em mim. Os olhos do espírito só começam a ver com acuidade, quando os do corpo entram a enfraquecer, o que ainda está longe de passar-se contigo (2011, 218e-219a).

Alcibíades ao contar isso, declara que Sócrates o ofendeu inqualificavelmente, depreciou a 
sua beleza, foi desprezado, dilacerado em seus sentimentos, no entanto admirava a "sua natureza, sua temperança e o domínio de si mesmo que lhe é característico $(2011,219 \mathrm{e})$. Alcibíades declara que não possuía meios de romper a companhia de Sócrates, pois jamais encontraria um modelo de homem tão sábio, firme e incorruptível. Na Guerra da Potideia Sócrates era superior a todos, quanto à superação das fadigas, das intempéries, da dor da fome, porém quando as provisões eram melhores, ele comia só e tranquilamente, não gostava de beber, mas quando era convidado, jamais ficava embriagado. Além disso, Alcibíades fala de sua coragem e heroísmo no campo de guerra.

Se quiserdes, vejamo-lo nos combates... Neste particular, também, seremos justos. $\mathrm{Na}$ batalha em que os comandantes me concederam a láurea da coragem, a este homem e a mais ninguém devi minha salvação. | Ferido como me achava, não quis abandonar-me e me levou, com minhas armas, para lugar seguro. Do meu lado, Sócrates, insisti com os generais para que te conferissem o prémio. Não tenho medo de que sobre isso me censures ou digas que é mentira. Porém os estrategos, levando em conta minha posição e desejando mesmo distinguir-me, tu te mostraste mais empenhado do que eles para que o prémio me fosse conferido (2011, 220e).

Alcibíades, continua a dizer que Sócrates é incomparável, que todos se encantam com a sua presença e ele finge ser um amante (erastes). Estes, depois sofrem, quando ele se revela apenas como um simples amigo (Philo). "A ti, Agatão, é que me dirijo neste momento: não te iludas com este homem; aprende conosco e não queiras ser como o tolo do provérbio, que só ficou esperto à custa de pancada" (2011, 222b). Sócrates pede a Agatão que não dê ouvidos a tal comentário, para que não promova a desunião entre eles. Agatão diz a entender que o porquê de Alcibíades querer sentar no meio deles, era para separá-los. Isso mesmo, disse Sócrates e pediu que Agatão retomasse sua direita. Logo em seguida, exclamou Alcibíades: "Quanta coisa eu tenho que aguentar deste homem!" (2011, 222e). Daí, pediu a Sócrates que deixasse Agatão sentar entre os dois, mas o filósofo afirmou que não poderia, visto que ele havia feito o elogio a ele, e cabia a Sócrates, conforme as regras do banquete, elogiar Agatão. Nisso gritou Agatão: "de jeito nenhum Alcibíades, poderei continuar aqui, sou forçado a mudar de lugar, para ser elogiado por Sócrates" (223a). Mas, mal Agatão se preparava para ficar à direita de Sócrates, um bando de beberrões adentrou a sua casa e a bagunça se generalizou. Logo, Fedro, Erixímaco e mais alguns, se retiraram e Aristodemo, cansado dormiu (2011, 223b-d).

\section{Modo de Vida}

Sócrates além dos ciúmes, teve adversários e inimigos, mas teve amigos e discípulos fervorosos que caminharam ao seu lado. Para Pierre Hadot, (1999, p.47) "A figura de Sócrates" foi primordial para a definição de filósofo e $O$ Banquete de Platão, "uma verdadeira tomada de consciência da situação paradoxal do filósofo no meio dos homens". Diante disso, Hadot (1999, p. 47-49) em um estudo, fixouse mais na figura mítica de Sócrates do que na da histórica, ou seja, investigou a presença de Sócrates, a do Herói, logo após a sua morte. É nesse estágio que o "Mito - Sócrates" produziu marcas indeléveis por toda a história da Filosofia. Xenofonte, Platão, dentre outros, escreveram sobre ele. Discípulos fundaram escolas animados por seu mestre. Antístenes fundou a Escola Cínica e preconizou a austeridade e a tensão, o que influenciaria o Estoicismo. Aristipo funda a Escola de Cirene, baseada numa "Arte de Viver" que influenciará o Epicurismo. Euclides funda a Escola de Megara, famosa pela arte da dialética. Platão funda a Academia, acompanha o seu mestre e cria o seu pensamento filosófico.

Estas fundações primaram pela contemplação, pelo discurso aliado à prática, pois estas escolas filosóficas eram antes de tudo uma maneira de viver, uma escolha de vida, uma opção existencial, "uma mudança total de vida, uma conversão de todo o ser, e, finalmente, a um desejo de ser e de viver de certa maneira" (HADOT,1999, p.18). O discurso filosófico de Sócrates era vinculado com a forma de viver e a filosofia um exercício que o preparava para a sabedoria. Exercícios espirituais que o transformavam interiormente, e seus discursos coadunavam com suas ações. Surgia, portanto um imenso movimento diante do "Mito Sócrates". A ideia de filosofia se vincula a este "modo de vida". "Modo de vida" cujo exemplo mítico está relacionado com as incessantes buscas pela virtude, pelo conhecimento e verdade, pois ele dizia: "sei que nada sei", "conhece-te a ti mesmo", "cuida de si". 
Sócrates, era um "um estranho à vida cotidiana". Hadot (1999, p11) faz menção a Immanuel Kant quando este alude que,

Os filósofos gregos antigos, como Epicuro, Zenão, Sócrates etc., permanecem muito mais fiéis à verdadeira Ideia do filósofo do que a que se fez nos tempos modernos. "Quando hás de, enfim, começar a viver virtuosamente?", disse Platão a um ancião que the pedia escutasse algumas lições sobre a virtude. Não se deve apenas especular, mas é necessário também, de uma vez por todas, pensar em praticar.

Sócrates era um estranho, vivia de acordo com o que ensinava. Nos diálogos platônicos é chamado de inclassificável (Átopos), e o que o torna Átopos é exatamente por ser o amante, o Eros da sabedoria. A estranheza, a atopia do filósofo no mundo humano, para Hadot é porque não se sabe onde classificá-lo, visto que não é um sábio e nem um homem como os demais. Vive o seu "Modo de vida", mesmo sabendo que a sabedoria "é um estado ideal e quase inacessível" (HADOT, 2012, p.22). Assim, a tal vida filosófica é vista pelos homens "ditos sábios", como estado de loucura, de inconsciência, portanto estranho à vida cotidiana.

\section{Encontro, Conhece-te a ti mesmo, Cuidado de si e do Outro}

O "encontro" é a abertura para o diálogo inflamado e o caminhar juntos corresponde ao encontro do olhar, do reflexo de si no olhar do outro, neste encontro de almas.

Segundo Delmar Cardoso (2006, p.27), o "encontro" é o elemento caracterizador da filosofia platônica, tensão entre natureza e cultura, cuja mediação é feita pelo homem, uma atuação privilegiada através do discurso filosófico, pois o homem, para Platão, era um homem para a pólis.

$O$ banquete na casa de Agatão é um "encontro". No avançar da madrugada, com alguns convivas já retirados, Aristodemo cansado, dorme. Ao acordar no alvorecer do dia, vê outras pessoas dormindo, enquanto Sócrates, Agatão e Aristófanes dialogavam ainda. Logo, Aristófanes cabeceando entrega-se ao sono e, já dia bem claro, Agatão também se rende. Sócrates acomoda os dois e vai embora dirigindo-se ao Liceu, acompanhado, "como de praxe por Aristodemo" (2011, 223d), o "orador".

De $O$ Banquete no qual Fedro era o simposiarca, para a obra Fedro em que ele dialoga somente com Sócrates, o encontro ocorre fora dos muros da cidade, com o sol quase a pino, sol do meio-dia, às margens do rio Ilissos, sob a sombra de um "plátano". Parece que era o tempo (kairós) exato para o plantio, pois antes, o lavrador filó-sofo (Philo - amigo ou Eros -amor; sóphos - sabedoria) já vinha preparando o terreno, desde o banquete. Prova disso é o resultado do fruto colhido ao término da obra Fedro, logo após a oração final de Sócrates, pois Fedro reivindica também o mesmo pedido que Sócrates fez aos deuses, "pois entre amigos tudo é comum" (2007, 279c). Deste "encontro", logo os dois se separam, cada um segue o seu caminho. Fedro, portanto está possuído por Eros, pois torna-se um amigo, um amante da Sabedoria como o seu mestre filósofo.

Pensa Hadot que $O$ Banquete é um monumento literário à memória de Sócrates, o ErosSócrates que é ao mesmo tempo, filho de Poros (Riqueza) e Penia (Pobreza). Para Diotima o Eros é filo-sofo, pois encontra-se entre a feiura e a beleza virtuosa, entre a ignorância e a sabedoria, entre o mortal e o imortal, além disso é consciente do nada saber.

Sócrates ou o filósofo é Eros: privado de sabedoria, de beleza, do bem, deseja, ama a sabedoria, a beleza, o bem. Ele é Eros, o que significa que ele é o Desejo, não um Desejo passivo e nostálgico, mas um desejo impetuoso, digno desse "caçador terrivel", que é Eros (HADOT, 1999, p.77).

Tal caçada era o que o impulsionava, a busca da sabedoria, a verdade, o falar a verdade (parrhesía) e, como Educador, cabia-lhe o oficio de despertar os homens, conforme inscrição délfica do "Conhece-te a ti mesmo" (gnôthi seautón), para depois, no "Cuidado de si" (epiméleia heautoú) dedicar-se ao cuidado com o outro.

No jogo amoroso onde se enfrentavam diversas dominações (a do amante buscando apoderar-se do amado, a do amado procurando escapar e, através dessa resistência, reduzindo o amante à escravidão), Sócrates introduz um outro tipo de dominação: a que é exercida pelo mestre de verdade e para qual ele é qualificado pela soberania que exerce sobre si (FOUCAULT, 2012, p.304). 
No Primeiro Alcibíades (2007, 129a), Sócrates pergunta a Alcibíades se é fácil conhecerse a si mesmo. Alcibíades responde que parece estar ao alcance de qualquer pessoa, outras são mais difíceis. Sócrates, diz que sendo fácil ou difícil, o que é certo é que conhecendo a si mesmo, saberá cuidar de si mesmo. O grande problema é que conhecer-se a si mesmo envolve uma ruptura radical com a vida cotidiana, com convenções e hábitos, daí tornar-se estranho ao cotidiano (Átopos), mas isso não significava que se devia afastar da cidade, das leis e dos outros, muito pelo contrário. Como se vê acima (Cf. acima, p.111-112 e a Nota 2) Alcibíades não se conheceu, portanto, não cuidou de si. Assim, não poderia cuidar dos outros.

Sócrates (Apologia) quando soube que Querofonte visitara o Templo de Delfos e havia consultado Pítia e, que esta lhe informara que Sócrates era o homem mais sábio, ele imediatamente dedicou a se examinar. Ao se examinar, pretendia conhecer-se a si mesmo e consequentemente, cuidar de si. Ao cuidar de si, no encontro com outros, no diálogo com todos, tentava despertar as pessoas, para que também peregrinassem pelos caminhos do conhecimento de si. Daí, o cuidar de si, torna-se extensão para o cuidado com o outro. Nesse processo, o Cuidado é o nutriente ativo que gera o Belo, o Justo o Bem. Eis, portanto o ofício do Cuidador, do Educador Filosofo, que sempre deverá retornar à Caverna (Alegoria da Caverna - Livro VII, A República de Platão), na qual tem por missão ajudar a quebrar os grilhões das amarras humanas, das certezas e dos sistemas. Porém, corre-se o risco de não ser compreendido, ser condenado, pois é um estranho, um louco, um sonhador.

Nas vésperas de se cumprir a execução de Sócrates, Critão, amigo de infância foi visitá-lo na prisão. Disse que tinha um plano, pretendia comprar os guardas e burlar os juízes para empreender a fuga do Mestre. Tentou convencê-lo, mas em vão. Sócrates disse:

"Meu caro Critão, tua dedicação é inestimável, no caso de afinar com o dever; não sendo assim, quanto mais extremada, mais condenável será. De início o que devemos considerar é se podemos ou não agir dessa maneira. Porque sempre tive por norma nas minhas deliberações, não agora somente, deixar-me apenas convencer do princípio que ao exame se me afigure o melhor. Não me é possível renegar meus argumentos no passado, somente por causa do que me aconteceu; ainda se me afiguram sensivelmente idêntico; continuo a tê-los na mesma conta de antes. $(2007,46 b)$. (...) Fica, pois, sabendo que no que respeita às minhas convicções, tudo que disseres em contrário será baldado (2007, 54d).

\section{Considerações Finais}

Vê-se que o pequeno trecho proposto para este estudo, conduziu a outros tantos pormenores e, a cada avanço, novos rumos surgiram. Banhar nas águas platônicas, implica um mergulhar cada vez mais profundo, num retiro de si (anacoreses socrática), numa busca para se conhecer. É tornar-se um pouco poeta da vida, num devir de si, numa reconquista de si, numa vigilância de si, numa simplicidade de si. Atento, Blaise Pascal legou um pensamento oportuno ao dizer que geralmente só imaginamos Platão e Aristóteles com grandes túnicas de pedantes. Eram pessoas honestas e como as demais pessoas, sorriam com os amigos e se divertiam. Ao fazer as Leis e sua Política fizeramnas brincando. "Era a parte menos filosófica e menos séria de sua vida. A mais filosófica e menos séria consistia em viver simples e tranquilamente" (PASCAL, 1999, p.118).

"Viver simples e tranquilamente". Ao Final do banquete, Sócrates vai ao Liceu, toma banho, realiza suas atividades diárias e só de tarde vai para casa repousar. Segundo Hadot, o fim deste diálogo, fez poetas sonharem. Friedrich Nietzsche escreve:

Ele enfrentou a morte com aquela calma com a qual, segundo descrição de Platão, deixara, ao alvorecer, o simpósio, como último dos beberrões, a fim de começar um novo dia, enquanto que, atrás dele, permanecem nos bancos e no solo, os comensais adormecidos, para sonhar com Sócrates, o erótico verdadeiro. O Sócrates moribundo tornou-se o ideal novo, nunca dantes visto, da nobre juventude grega. Platão o jovem grego típico, prostrou-se diante de todos, com dedicação fervorosa de alma entusiasta, ante tal figura (NIETZSCHE, 2005, p.78).

A ocupação e preocupação de Sócrates dedicadas aos homens de seu tempo, confere à contemporaneidade, a todos os educadores, a necessidade de cuidado com as sementes e com o 
cultivo dos jardins.

No retorno às perguntas iniciais deste estudo, sobre a "ironia" a fala de "Aristodemo", "alguma mensagem essencial", "caminhos", parece que todo o trecho (179a) partilha com a ironia socrática quanto ao exame diário da vida, quanto o poder da oralidade através do diálogo, quanto à fala viva na busca pela verdade, pelo Cuidado de si e dos Outros, pelos questionamentos diante de uma suposta e confiante liberdade a nós dada. Certamente algo ainda pode acontecer, depois de mais de 2.400 anos, o tavão continua a voar e a incomodar as almas noutro tempo histórico, no aqui-agora, num mundo atual de tantos sábios e Alcibíades, comemorações e vitórias, mas ele olha à distância e quando estamos a sós, ele, sem medo das multidões, vem ao encontro simplesmente. Daí, pode-se sentir os ecos desse passado, o perfume do banho tomado, o som das sandálias a se aproximarem e então, como Aristodemo uma pergunta se torna inevitável:

- Sócrates, porque estais tão Belo?

Certamente, este Eros-Educador repetiria:

- Fui convidado e "prometi comparecer hoje. Esse é o motivo de me ter aprontado".

Educadores preparem-se, pois o sympósium começou!!!

\section{Notas}

1 Estudos indicam que este sympósium $(O$ Banquete) ocorreu em torno de 416 a.C. período funesto para os helenos, reinício da Guerra do Peloponeso através do governo do então, General Alcibíades. Na escola de Platão, na Academia, o sympósium era uma constante, pois discutia os temas mais relevantes para o bem-viver na pólis. De uma certa forma, portanto, atualmente o sympósium possui uma conotação acadêmica. Quanto à temática sobre o Eros na obra $O$ Banquete, o sentido do Amor Erótico (amor pelos rapazes) é posto em debate sobre a relação entre os amantes (Erastes) e os amados (Erômenos). Certamente, o pensamento filosófico platônico $\mathrm{d} O$ Banquete foi e será um divisor de águas para a civilização ocidental, cujas ondas avançaram pela sociedade helenística e romana, pela cristandade, até os nossos dias.

2 "O povo, preocupado na época com a enormidade de sua depravação na vida diária e também com seus desígnios, revelados em cada uma das muitas intrigas em que se envolvia, passou a hostilizá-lo, considerando-o um aspirante à tirania; de fato, embora na vida pública ele tratasse dos assuntos relativos à guerra da melhor maneira possível, na vida privada ele ofendia todos os cidadãos com sua conduta, levando-os a confiar a cidade a outras mãos e a arruiná-la por isto ao fim de não muito tempo" (TUCÍDIDES, 2001, p.364).

3 A memória era muito cultuada pelos helenos, pois estava ligada à oralidade e representada por uma importante deusa, a "Mnemosyne- Mnemósina: (Titânida - filha de Geia e Urano), deusa da personificação da Memória". Teve filhas com Zeus: “(...) São nove as Musas: Calíope, musa da poesia épica; Clio, musa da história; Érato, musa da poesia erótica; Euterpe, musa da poesia lírica; Melpômene, musa da tragédia; Polínea, musa da poesia sacra; Talia, musa da comédia; Terpsícore, musa da dança e do canto e Urânia, musa da astronomia" (SILVEIRA, 2010, P.65).

\section{Referências}

ARISTÓFANES. Comédias III - Lisístrata, Tesmoforiantes, Ranas, Asambleístas, Pluto. Tradução Luis M. Macía Aparicio. Madrid: Editorial Gredos S.A., 2007.

CARDOSO, Delmar. A Alma como centro do filosofar de Platão: uma leitura concêntrica do Fedro à luz da interpretação de Franco Trabattoni. São Paulo: Edições Loyola, 2006.

FOUCAULT, Michel. História da Sexualidade 2. O uso dos prazeres. Tradução Maria Thereza da C. Albuquerque. São Paulo: Edições Graal Ltda, 2012.

GIORDANI, Mário Curtis. História da Grécia. Petrópolis: Editora Vozes, 1984.

HADOT, Pierre. O que é Filosofia Antiga. Tradução Dion Davi Macedo. São Paulo: Edições Loyola, 1999.

Elogio da Filosofia Antiga. Tradução Flávio F. Loque; Loraine Oliveira. São Paulo: Edições Loyola, 2012.

JAERGER. Werner. Paideia. A formação do homem grego. Tradução Arthur M. Parreira. São Paulo: Martins Fontes, 2001.

NIETZSCHE. Friedrich. A origem da Tragédia. 
Proveniente do Espírito da Música. Tradução. Márcio Puglirse. São Paulo: Madras, 2005.

PASCAL. Pensamentos. Tradução Olívia Bauduh. São Paulo: Editora Nova Cultural Ltda, 1999. (Coleção os Pensadores)

PLATÃO. Apologia à Sócrates. Tradução Enrico Corvisieri. São Paulo: Editora Nova Cultural Ltda, 1999. (Coleção os Pensadores)

\section{Critão, Menão, Hípias Maior e}

Outros. Tradução Carlos Alberto Nunes. Belém: Editora Universidade do Pará, 2007.

\section{Fedro, Cartas e O Primeiro}

Alcibíades. Tradução Carlos Alberto Nunes. Belém: Editora Universidade do Pará, 2007.

\section{O Banquete. Tradução Carlos}

Alberto Nunes. Belém: Editora Universidade do Pará, 2011.
PLATONE. Tutti Gli Scritti. Tradução Giovanni Reale. $7^{\mathrm{a}}$ ed. Milão: Bompiani, 2014.

PLUTARCO. Vidas paralelas: Alcibíades e Coriolano. Tradução Maria do Céu Fialho; Nuno Simões Rodrigues. Coimbra: Universidade de Coimbra, 2010.

SILVEIRA, Carlos Roberto da. A Inveja e a Justiça na Poesia Filosófica dos Aedos. Revista Eletrônica Theoria, Sítio http://www.theoria.com.br - ISSN: 1984-9052, V. II, Número III, p. 62-75, 2010.

TUCÍDIDES. História da Guerra do Peloponeso. Tradução Mário da Gama Kury. Brasília: Editora Universidade de Brasília, 1987.

VEYNE, Paul (Org.). História da vida privada I: do Império Romano ao Ano Mil. Tradução Hildegard Feist. São Paulo: Companhia das Letras, 2006.

\section{Sobre o autor:}

Carlos Roberto da Silveira: Professor na Faculdade Católica de Pouso Alegre e na Escola de Enfermagem Wenceslau Braz. Graduado em Administração de Empresas(FAI). Especialista em Psicopedagogia Institucional e Clínica (UNIVAS). Mestre em Filosofia (PUC-CAMP). Doutor em Filosofia (PUC-SP) e Pós-doutorando em Educação (USF).

Agradeço à Comissão de Aperfeiçoamento de Pessoal de Nível Superior (CAPES) pela Bolsa de Pós-doutorado a mim concedida. Agradeço aos docentes e discentes do Programa de Pós-graduação Stricto Sensu em Educação da Universidade São Francisco de Itatiba (USF), donde este artigo-fruto foi colhido, não nos "Jardins de Adônis", mas nos "Jardins de Francisco", no labor de nossas aragens, plantios, cultivos, colheitas e "banquetes".

Recebido em 15/06/2014

Aprovado em 11/12/2014 